\title{
Plagiera eller referera vetenskapligt? En studie om vad studenter behöver lära sig för att bli bättre på referathantering
}

\author{
Josefin Hellman ${ }^{\text {r* }}$ och Anja Thorsten ${ }^{2}$ \\ ${ }^{1}$ Stockholms universitet; ${ }^{2}$ Linköpings universitet
}

\begin{abstract}
Den här artikeln fokuserar på studenters referathantering $\mathrm{i}$ examinerande uppgifter i högre utbildning och vad studenterna behöver urskilja för att utveckla detta kunnande. Dataunderlaget består av intervjuer och studenttexter. Resultatet bygger på två typer av analyser. Genom en fenomenografisk analys framkom fyra kategorier som beskriver kvalitativt skilda sätt att erfara och hantera referatet. Via en variationsteoretisk analys, utifrån skillnaderna mellan kategorierna, påvisades sedan fyra aspekter som kan anses kritiska för att lära sig referathantering. De beskriver att studenter behöver urskilja att A) textens innehåll kan separeras från dess form, B) det finns ett idéinnehåll i hela källtexten och i längre textavsnitt, C) källans idéinnehåll ska fylla en funktion i relation till den egna textens idéinnehåll och D) referathantering placerar in den egna texten i ett vetenskapligt sammanhang. De kritiska aspekterna som framkommit i studien kan användas som underlag för att planera undervisning i akademiskt skrivande i högre utbildning.
\end{abstract}

Nyckelord: referat, akademiskt skrivande, studenters skrivande, fenomenografi, variationsteori

This study investigates students' ability to cite and reference in their higher education coursework, and more particularly what needs to be made visible for students to develop this ability. The data consists of interviews and student texts. The results are based on two types of analyses. Through a phenomenographical analysis, four qualitatively different approaches to referencing were identified. Using the variation theory, an analysis of the differences between the approaches then identified four critical aspects for learning how to reference. Students need to see that a) the content in a text can be separated from its form, b) there are some main ideas present in the whole source text and in longer sections of the text, c) the ideas from the source text have to be relevant to the student's own text, and d) referencing places a text in an academic context. The critical aspects identified in this study can be used for planning the teaching of academic writing in higher education.

Keywords: referencing, academic writing, plagiarism, phenomenography, variation theory

\section{INTRODUKTION}

Referathantering är en självklar del av akademiskt skrivande, men att studenter vet hur man refererar och hanterar källtexter på ett adekvat sätt är inte självklart. Plagiering är idag den vanligaste disciplinförseelsen vid svenska lärosäten (UKÄ, 20I9). Detta kan emellertid till stor

\footnotetext{
*Författarkontakt: josefin.hellman@su.se
} 
del betraktas som ett uttryck för okunskap, snarare än fusk (Sutherland-Smith, 2019; Howard, Serviss \& Rodrigue, 20IO). Flera avhandlingar om studenters skrivande (t.ex. Ask, 2007; Lennartson-Hokkanen, 20I6) har betonat att det akademiska skrivandet ofta är en stor utmaning för nya studenter. Vem som ska skyllas för att studenterna har svårigheter med detta är emellertid inte uppenbart. Det tycks dock som att studenterna många gånger oförtjänt pekas ut som syndabockar i diskursen om en skrivkris (Malmström, 20I7). Att studenter som kommer direkt från gymnasiet kan behärska det akademiska skrivandets komplexa referathantering verkar exempelvis inte rimligt (Östlund-Stjärnegårdh, 2006). Studenter i högre utbildning behöver alltså stöd och undervisning för att utveckla en adekvat referathantering, något som också har framhållits i forskning (se Refaei, Kumar, Wahman \& Peplow, 2017; Vardi, 2012).

Den universitetslärare som vill undervisa om referathantering stöter emellertid på flera utmaningar. För det första tycks det finnas något skenbart enkelt med att referera. Fokus kan hamna på att ge studenterna tillgång till referensguider eller information om plagiering, men detta verkar inte utveckla studenternas referathantering (Badenhorst, 20I9; Refaei et al., 20I7). För det andra kan läraren ha svårt att lära ut det akademiska skrivandets konventioner, såsom normer knutna till referathantering, om hen lärt sig dessa implicit (Hoel, 20ro). För det tredje verkar antiplagieringsmjukvara, så som Urkund, inte heller hjälpa. Studenterna tycks då försöka hitta sätt att behaga systemet snarare än att fokusera på att bli bra skribenter (Weber-Wulff, 2019).

Idag är forskningen om undervisning i referathantering begränsad, särskilt i en svensk kontext. För att kunna utveckla undervisningen rörande referathantering behöver själva kunnandet avtäckas och synliggöras. Syftet med föreliggande studie är att öka kunskapen om studenters referathantering och beskriva vilka aspekter som är kritiska för studenter att urskilja för att de ska kunna utveckla sin förmåga att referera. I relation till högskolans uppdrag om breddad rekrytering (Högskolelag, 20I5) och att studenter inte bara ska ha möjlighet att påbörja sina studier utan också ges förutsättningar att fullfölja dem, blir detta särskilt viktigt att beakta.

\section{REFERATHANTERING SOM AKADEMISK SKRIFTSPRÅKSKOMPETENS}

En utgångspunkt för denna studie är att akademisk skriftspråkskompetens förstås som academic literacies (se Lea \& Street, 1998). Utifrån ett sådant synsätt kan akademiskt skrivande sägas omfatta såväl läs- och skrivförmåga som förmågan att anpassa det skrivna till ett socialt sammanhang. Vårt sätt att förstå världen avspeglar sig således i vårt sätt att tala, skriva och tänka och det är alltid knutet till ett sammanhang, och därmed till olika diskurser. Akademiskt skrivande är att betrakta som flera diskurser, alltså olika sätt att tala, skriva och tänka inom olika fält i högre utbildning, snarare än en gemensam diskurs (Lea \& Street, 1998). Det innebär bland annat att referathanteringen och konventioner rörande vilket referenssystem eller vilken referensguide som ska användas kan variera utifrån ämnesområde, lärosäte och lärare samt förändras över tid (Pecorari \& Shaw, 20I2).

För att synliggöra de gemensamma, respektive diskursspecifika, drag som finns inom referathantering och akademiskt skrivande kan begreppen allmänakademiska och ämnesspecifika normer användas (jfr Blückert, 20Io). Allmänakademiska drag i texter har tidigare beskrivits av Ask (2007). Hon menar exempelvis att akademiska texter kan antas visa tydliga tecken på kritisk-analytisk kompetens och förmåga att följa akademiska textkonventioner, såsom hur källtexter ska införlivas i den egna texten. Gemensamt är också att texter ska uppvisa lyhördhet för stil- och skriftspråkskonventioner. Vilka konventionerna är kan däremot variera utifrån den ämnesspecifika kontexten. 
Referathantering som akademisk skriftspråkskompetens är en komplex aktivitet. Jakobs (2003) samt Eriksson och Mäkitalo (2013) belyser att referathantering inbegriper såväl att läsa och förstå en källtext som att välja ut relevanta delar och förstå hur de kan ta plats i den nya texten. Referathanteringen kan även knytas till intertextualitet och skribentens förmåga att införliva den egna rösten i skrivandet. Lillis (2003) menar att skribenten då deltar i en dialogisk aktivitet som gör det möjligt att läsa och tolka det andra skrivit på nya sätt.

\section{STUDENTERS FÖRMÅGA ATT REFERERA}

Nybörjarstudenter saknar ofta akademisk skriftspråkskompetens och det tycks mödosamt för dem att erövra denna (se Ask, 2007; Lennartson-Hokkanen, 20I6). Parallellt med detta beskrivs att allt fler studenter skriver texter som är identiska eller mycket lika andra texter och att skribenten använt källtexten som om den vore hens egen (se UKÄ, 20I9). Studenters referathantering och akademiska skriftspråkskompetens tycks alltså nära knutna till plagiering som företeelse. I föreliggande studie definieras plagiering som att studenten skriver texter som är identiska eller mycket lika andra texter. Plagiering saknar dock enhetlig definition och nämns inte explicit i Högskoleförordningen (SFS I993:I00).

Ett närliggande begrepp som kan användas för att beskriva plagiering och textnära referathantering är patchwriting, vilket definieras som "Copying from a source text and then deleting some words, altering grammatical structures, or plugging in one-for-one synonym-substitutes" (Howard, 1993, s. 233). Patchwriting innebär alltså att studenten i huvudsak kopierat källtexten och sedan flyttat runt, eller bytt ut, enstaka ord eller meningar.

Plagiering och textnära referathantering kan ses som ett utvecklingssteg eller uttryck för att studenten ännu inte behärskar den aktuella diskursen (Gravett \& Kinchin, 2020; Howard et al., 20IO). Bristande referathantering kan också hänga samman med att skrivkonventioner många gånger tas för givna och behöver synliggöras för studenter, såväl som för lärare (se Staaf, 2015; Pecorari \& Shaw, 20I2). Vardi (20I2) menar istället att patchwriting inte bör betraktas som ett utvecklingssteg, att undervisning i referathanering som intertextualitet gör att behovet att skriva textnära referat minskar. Elander, Pittam, Lusher, Fox och Payne (2010) menar att för att få syn på referathanteringens intertextuella aspekter behöver studenten förstå hur den egna rösten kan användas i texten och fokusera på kärnbudskapet i källtexten istället för att se till delarna. Att använda sin röst i relation till en källtext kan också ge ett slags ägande av den egna texten, menar Hutchings (20I4).

En studie av Hounsell (1997) kan bidra med att beskriva hur studenter erfar referathantering. Hounsell intervjuade studenter om uppsatsskrivande i historia och kombinerade det med en analys av deras texter. Resultatet beskriver tre kvalitativt skilda uppfattningar av uppsatsskrivande. Den första benämns att se uppsatsen som återgivning. Här använder studenten många källor och sätter samman dem, men en övergripande idé som driver texten saknas. När studenten ser uppsatsen som synpunkt drivs den egna texten av de åsikter hen vill framföra, men källorna används inte som stöd i resonemangen. I den sista kategorin, uppsatsen som diskussion, använder studenterna källorna som utgångspunkt för att diskutera en övergripande fråga. Enligt Hounsell är det den sistnämnda kategorin som är eftersträvansvärd.

Många studenter behärskar alltså inte det akademiska skrivandets komplexa referathantering och behöver undervisning i detta, vilket bland annat lyfts av Refaei et al. (20I7) och Vardi (20I2). För att möjliggöra undervisning som utvecklar studenternas förmåga att referera behövs emellertid mer kunskap om hur studenter hanterar och erfar referatet idag och vad som behöver undervisas för att de ska utveckla detta kunnande. Föreliggande studie avser att bidra med sådan kunskap. 


\section{METOD}

Studiens metodologiska och teoretiska ramverk utgår ifrån fenomenografi och variationsteori. Fenomenografi är en forskningsansats där intresset är att beskriva hur fenomen i världen kan uppfattas ${ }^{\mathrm{I}}$ och erfaras (Marton, 198I). Marton (198I) beskriver att forskaren vid en fenomenografisk ansats intar andra ordningens perspektiv. Det innebär att forskaren försöker se fenomenet ur informantens ögon och förstå den logik som ligger bakom uttalanden och handlanden (Marton, 20I5). Metoden lämpar sig särskilt bra för forskning där intresset handlar om lärande, eftersom resultatet fångar olika sätt som ett lärandeinnehåll kan erfaras (Marton \& Booth, 2000). Lärandeinnehållet benämns som lärandeobjekt och blir då det fenomen som undersöks i studien. Lärandeobjektet i föreliggande studie är att referera $i$ examinerande uppgifter $i$ högre studier. Vid en fenomenografisk ansats är inte syftet att beskriva enskilda individers uppfattningar av lärandeobjektet, istället söks de kvalitativt skilda uppfattningar som framkommer i datamaterialet (Marton, 198I). Det innebär att en och samma individ kan ge uttryck för uppfattningar som placeras i olika kategorier. För att inte bara säga något om hur ett lärandeobjekt kan uppfattas, utan även beskriva hur undervisningen kan möjliggöra att elever och studenter utvecklar nya sätt att erfara lärandeobjektet, utvecklades variationsteorin ur fenomenografin (Runesson, 2017).

Variationsteorin fokuserar på relationen undervisning och lärande (Marton, 20I5). Grundtanken är att människor erfar olika aspekter av sin omvärld och att lärande innebär ett förändrat erfarande där andra och nya aspekter urskiljs (Marton, 20I5). Experten har urskilt aspekter som novisen ännu inte ser. Till exempel kan den skicklige skribenten hantera en rad aspekter (som rör struktur, ordval, berättarröst etc.) som den mer oerfarna skribenten ännu inte har urskilt. Vissa aspekter är kritiska att urskilja för att kunna erfara ett lärandeobjekt på ett speciellt sätt. Dessa benämns som kritiska aspekter (Marton, 20I5; Lo, 20I4). Marton (20I5) framhåller att de kritiska aspekterna måste sökas efter, inte bara i själva ämnet, utan även hos dem som ska lära. Enligt Pang och Ki (2016) bör därför en fenomenografisk analys ligga som grund för de kritiska aspekterna. Kategorierna i ett fenomenografiskt utfallsrum beskriver hur ett lärandeobjekt kan uppfattas. Genom att analysera skillnaderna mellan vilka aspekter som erfars i kategorierna, går det att finna vilka aspekter som är kritiska att urskilja för att hantera lärandeobjektet på önskat sätt.

I föreliggande studie har vi gjort en fenomenografisk analys, vilken sedan ligger till grund för de kritiska aspekter som beskrivs. På så sätt är vår strävan att vi dels kan säga något om hur förmågan att referera $i$ examinerande uppgifter i högre studier kan hanteras bland studenter, men också något om vad undervisning om referatskrivande skulle behöva fokusera på.

Genomförande, urval och etik

Studien genomfördes på en språkverkstad ${ }^{2}$. De studenter som besökte språkverkstaden för handledning erbjöds att delta. Urvalet var således ett så kallat bekvämlighetsurval (se Bryman, 20II). Studiens empiriska material omfattas av II transkriberade intervjuer med I3 studenter och deras texter som kunde vara uppsatser eller kursuppgifter av olika slag (se Tabell I). Några av studenterna skrev i par och intervjuades då tillsammans. Kvalitativa semistrukturerade intervjuer

1 Uppfattningar ska i detta sammanhang inte tolkas som åsikter, utan ska istället förstås som sätt att erfara och urskilja världen.

2 Språkverkstäder finns idag på de flesta lärosäten i Sverige och deras verksamhet syftar i huvudsak till att stötta studenter i akademiskt skrivande. Se Lennartson-Hokkanen (2016) för en utförligare beskrivning av språkverkstäders arbete. 
utfördes (jfr Kvale \& Brinkmann, 20I4) utifrån en intervjuguide med följande teman: syftet med källhänvisning, referensens placering och utformning, att samla och soura och referatets placering $i$ relation till den egna rösten. Samtliga intervjuer genomfördes i det rum som vanligen används för handledning på språkverkstaden. Intervjuerna spelades in med hjälp av mobiltelefon och transkriberades sedan i mer formell skriftspråklig karaktär (jfr Kvale \& Brinkmann, 20I4).

Tabell ${ }_{\text {I. }}$ Översikt över datainsamlingen

\begin{tabular}{|c|c|c|c|c|c|}
\hline Student & $\mathbf{L I} / \mathbf{L 2}^{*}$ & $\begin{array}{c}\text { Terminer på } \\
\text { svensk högskola }\end{array}$ & $\begin{array}{l}\text { Typ av skriftlig examination, } \\
\text { antal sidor }\end{array}$ & Intervjulängd & Ämnesdisciplin \\
\hline Erika & LI & 5 & Självständigt arbete, 2 sidor & $15 \mathrm{~min}$ & Religionshistoria \\
\hline Petra & LI & 7 & \multirow{2}{*}{ Självständigt arbete, 25 sidor } & \multirow{2}{*}{$34 \mathrm{~min}$} & \multirow{2}{*}{ Barn- och ungdomsvetenskap } \\
\hline Mia & LI & 5 & & & \\
\hline Laila & $\mathrm{L}_{2}$ & 4 & Hemtentamen, 7 sidor & $28 \mathrm{~min}$ & Barn- och ungdomsvetenskap \\
\hline Esram & $\mathrm{L}_{2}$ & I & \multirow{2}{*}{ Självständigt arbete, 5 sidor } & \multirow{2}{*}{$47 \mathrm{~min}$} & \multirow{2}{*}{ Sociologi } \\
\hline Nala & $\mathrm{L}_{2}$ & 5 & & & \\
\hline Niklas & LI & 5 & Självständigt arbete, 34 sidor & $32 \mathrm{~min}$ & Historia \\
\hline Mimmi & LI & 7 & Självständigt arbete, 2 sidor & 3I $\mathrm{min}$ & Didaktik \\
\hline Pourim & $\mathrm{L}_{2}$ & 7 & Självständigt arbete, 22 sidor & $26 \mathrm{~min}$ & Barn- och ungdomsvetenskap \\
\hline Moa & LI & 5 & Självständigt arbete, 24 sidor & $25 \mathrm{~min}$ & Etnologi \\
\hline Paula & LI & 7 & Självständigt arbete, 40 sidor & $24 \mathrm{~min}$ & Sociologi \\
\hline Simon & LI & $\mathrm{o}$ & Hemtentamen, 6 sidor & $31 \mathrm{~min}$ & Barn- och ungdomsvetenskap \\
\hline Irina & $\mathrm{L}_{2}$ & $\mathrm{o}$ & Hemtentamen, 5 sidor & $23 \mathrm{~min}$ & Svenska \\
\hline
\end{tabular}

*Studenter med svenska som förstaspråk (LI), respektive studenter som lärt sig svenska senare i livet (L2).

Vetenskapsrådets (2007) etiska riktlinjer har följts under studien. De deltagande studenterna fick information om studien såväl muntligt som skriftligt och gav sitt skriftliga samtycke till att delta. Efter intervjun överfördes ljudfilen till en extern hårddisk och raderades från mobiltelefonen för att skydda den intervjuades integritet. Texterna som studenterna skrivit och intervjutranskriptionerna har anonymiserats med fingerade namn och personuppgifterna har behandlats konfidentiellt utifrån aktuell lagstiftning. Studiens data har enbart använts i forskningssyfte.

Analys

Analysen är induktiv och bygger således enbart på dataunderlaget. Analysarbetet har skett i fyra steg med en strävan att inta andra ordningens perspektiv och att finna kvalitativt skilda beskrivningskategorier (jfr Marton \& Booth, 200o) som kan utgöra en grund för att finna kritiska aspekter (Pang \& Ki, 20I6). Även om nedanstående steg beskrivs i en kronologisk ordning, påverkade nya analyser tidigare analyser, vilket gjorde att det i själva verket skedde en växling mellan stegen.

I det första steget gjordes en översiktlig analys av studenternas texter. Notiser gjordes om typiska sätt för studenten att hantera referatet. Det rörde sig till exempel om referensernas placering, eller om språket i referatet skiljde sig markant från språket i resten av texten. Dessutom jämfördes studenttexten och källtexten avseende hur lika texterna var och vilken typ av förändring som var gjord. Denna översiktliga textanalys användes sedan som underlag i intervjuerna tillsammans med intervjuguiden. 
Det andra steget bestod av en fenomenografisk analys av de transkriberade intervjuerna tillsammans med studenternas texter. Utgångspunkten var att en analys av både intervjuer och studenternas texter kan fördjupa analysen, i likhet med det tillvägagångssätt som Hounsell (I997) och Thorsten (20I8) använder. Inledningsvis lästes det transkriberade materialet igenom för att lära känna det och studenttexterna lästes på nytt. Sedan var strävan att inta andra ordningens perspektiv och söka efter vilka olika typer av uppfattningar som framkom i dataunderlaget (jfr Marton \& Booth, 2000). I varje transkription och dess medföljande studenttext lyftes centrala delar ut. I de delar som valdes ut syntes uttryck för olika sätt att erfara referathantering. När datamaterialet från alla studenter hade gåtts igenom jämfördes de utvalda delarna. Det innebar att studenters utsagor och texter jämfördes med andra studenters utsagor och texter, men även med andra delar från samma intervju eller text (jfr Dahlgren \& Johansson, 20I5). Strävan var inte att beskriva enskilda studenters uppfattningar utan kvalitativt skilda sätt att erfara att referera (jfr Marton, 198I). Det innebär att utsagor från en och samma student kan finnas med i flera kategorier. Ett första utfallsrum bestående av fyra kategorier växte fram. Kategorierna ordnades hierarkiskt baserat på Marton och Booth (2000), vilket innebar att de olika kategorierna beskriver ett allt mer nyanserat och komplext erfarande.

I ett tredje steg söktes kritiska aspekter. Mellan varje kategori framkom en eller flera aspekter som beskriver skillnaden mellan dem. Utsagor och studenttexter från de olika kategorierna jämfördes och ställdes i relation till det kunnande som eftersträvas (jfr Pang \& Ki, 20I6). I analysen framstod fem aspekter som kritiska för att utveckla det avsedda kunnandet.

I det färde steget gjordes en reanalys av allt datamaterial. Det innebar att transkriptioner och studenttexter analyserades igen. Då gjordes vissa förändringar i utfallsrummet vilket ledde till att det specificerades. Detta ledde även till att de kritiska aspekterna reviderades och istället för fem aspekter beskrevs nu fyra aspekter som kritiska.

\section{RESULTAT}

Resultatet presenteras i två delar. Först beskrivs det fenomenografiska utfallsrum som ger svar på hur studenter erfar och hanterar referatet. Sedan beskrivs kritiska aspekter för lärandet. Dessa svarar mot vad studenter behöver urskilja för att kunna referera och kan sägas representera delar av det studenter behöver urskilja för att referera i skriftliga examinationer $i$ högre studier.

\section{Studenters skilda sätt att erfara referathantering}

Fyra kvalitativt skilda sätt att erfara och hantera referatet i examinerande uppgifter framträdde i datamaterialet och dessa beskrivs i fyra kategorier. Att referera ses som att I) omformulera kortare textavsnitt, 2) sammanfatta en källas idéinnehåll, 3) relatera källans idéinnehåll till annat idéinnehåll och 4) delta i ett vetenskapligt sammanhang. Kategorierna är hierarkiska och det mest komplexa erfarandet beskrivs i kategori 4. Kategori 2, 3 och 4 är dessutom inkluderande. Detta innebär att kategori 2 ryms i kategori 3 . Kategori 4 kan vidare sägas rymma både kategori 2 och 3 (se Figur I).

\section{Ser att referera som att omformulera kortare textavsnitt}

I denna kategori ses referathantering som att klipp-och-klistra med olika delar från källtexten. Fokus är att omformulera tillräckligt mycket för att bli godkänd på uppgiften. Refererandet beskrivs som svårt och onödigt, eftersom källtexten "är så bra /.../ att det är svårt att skriva om det" (Mia). Källtextens form och innehåll i enskilda textavsnitt erfars som en helhet som är svår, eller omöjlig, att dela på. Eftersom studenten vet att texten, trots detta, måste skrivas om och 
(4) Ser att referera som att delta i ett vetenskapligt sammanhang

(3) Ser att referera som att relatera källans idéinnehåll till annat idéinnehåll

(2) Ser att referera som att sammanfatta en källas idéinnehåll

(1) Ser att referera som att omformulera kortare textavsnitt

Kommentar: Kategorierna är hierarkiska och det mest komplexa erfarandet beskrivs i kategori 4. Kategori 2, 3 och 4 är dessutom inkluderande.

Figur I. Fyra kvalitativt skilda sätt att erfara och hantera referatet $i$ examinerande uppgifter

skrivas med egna formuleringar, så används olika strategier för att lyckas med uppgiften. De formuleringar som finns i källtexten är utgångspunkt i det egna skrivandet. Mia beskriver att hon utgår från några meningar i källtexten och sedan gör vissa ändringar:

Då brukar jag använda mig av synonymer och så byter jag ut. /.../ Eller så vänder jag på meningarna. Jag kastar om början och slut. (Mia)

Detta kan tolkas som att hon ser källtexten som bestående av flera informationsenheter. I sin textbearbetning utgår hon från en av dessa enheter och strävar efter att göra förändringar i den. Varje enhet behandlas som ett legobygge, där vissa delar kan bytas ut (genom att använda synonymer) och andra delar placeras om (genom att byta plats på delar av meningen). Fokus i omarbetningen ligger på källtextens form, det vill säga dess struktur, ordval och meningsbyggnad. Innehållet erfars som inbäddat i själva textstrukturen. När källtexten omarbetas urskiljs innehållet på ordnivå, eller ibland på meningsnivå, och då byts enskilda ord ut eller så görs omflyttningar i meningarna.

Irina har en liknande strategi. Tabell 2 visar Irinas text och den källtext hon utgår från.

Tabell 2. Jämförelse mellan studenttext och källtext

\begin{tabular}{|c|c|}
\hline Studenttext & Källtext \\
\hline Utdrag från lrinas hemtentamen: & $\begin{array}{l}\text { Utdrag från källtexten till programmet "Att sakna ord" från } \\
\text { serien Från vardagssnack till skolspråk från UR Play (20I7): }\end{array}$ \\
\hline $\begin{array}{l}\text { "Ann [sic!] Wisselgren som är danslärare visar hur hon } \\
\text { använder ämne språk samtidigt som hon undervisar. } \\
\text { Susanne Jönsson lär ut ämnesord i matematik med hjälp } \\
\text { av domino." }\end{array}$ & $\begin{array}{l}\text { "Vi får se lararen Susanne Jönsson ta hjälp av domino i mate- } \\
\text { matik for att lära ut ämnesord. / .../ Anna Wisselgren som } \\
\text { är danslärare, visar hur hon lär ut ämnesspråket samtidigt } \\
\text { som eleverna lär sig koreografi." }\end{array}$ \\
\hline
\end{tabular}


För att inte skriva av källtexten har Irina bytt plats på meningarna och bytt ut vissa formuleringar. Hon beskriver att hon strävar efter att inte ha exakt samma formuleringar i sin egen text som i källtexten, för att på så sätt undvika att texten ses som plagiat. Irina beskriver vidare att hon "blev lite uppskrämd över alla de här reglerna och kursläraren tryckte väldigt hårt på dem". Hon försöker därför följa referensguiden men blir förvirrad av att det finns olika guider och att det är så många regler. Irina fokuserar mycket på att inte plagiera och försöker att utröna var gränsen för plagiat går. Hon menar att det inte är plagiat om hon använder "en synonymordbok och hittar ord som är vetenskapliga och byter ut alla ord och gör om meningen. Då blir det inte plagiat." Hon funderar också på om det skulle vara plagiat om hon skulle direktöversätta en text på sitt modersmål till svenska. Detta kan tolkas som att hon har källtextens formuleringar som bas, men ser till att den egna texten inte är exakt likadan.

Liksom Irina ser Laila referathanteringen som komplicerad. Hon beskriver den också som onödig och lärarna beskrivs som nitiska i sin rättning:

Än idag har jag inte förstått varför det är så viktigt. Det kan ju hända att man missar. Man blir ju blind av all text, man ser ju på tretusen ord. Sen kommer läraren och säger ' $F^{3}{ }^{3}$. Varför då? 'Du glömde parentesen och ett kommatecken.' Give me a break. (Laila)

Att Laila säger "Give me a break" signalerar att hon tycker att referatreglerna är överdrivna. Hon ser användandet av dem som ett onödigt ont som krävs för godkänt på uppgiften. Detta kan tolkas som att Laila inte ser syftet och funktionen med att referera.

När att referera erfars som att omformulera kortare textavsnitt blir alltså den struktur, meningsbyggnad och de ordval som finns i källtexten utgångspunkten för det egna skrivandet. De möbleras om och byts ut och på så sätt ses den egna texten som skriven med egna ord. Att följa en referensguide ses som onödigt och komplicerat. Studenten tycks inte ha förstått refererandets intertextuella funktion och referathanteringen kretsar istället mycket kring att försöka följa reglerna (d.v.s. att inte skriva av och att följa ett referenssystem) för att bli godkänd på uppgiften.

\section{Ser att referera som att sammanfatta en källas idéinnehåll}

Referathantering ses i denna kategori som att de idéer och tankar som finns i varje källa ska sammanfattas. Det innebär att när källtexten läses fokuserar studenten på att förstå textens innehåll och budskap för att sedan skriva en sammanfattning av det. Laila beskriver detta i nedanstående excerpt.

Jag liksom sammanfattar det hon har sagt. Och det jag skriver är min sammanfattning, min förståelse av den texten. (Laila)

När Laila använder uttrycket "min förståelse av texten" kan det tolkas som att hon själv behöver förstå källtexten för att hon ska kunna skriva en sammanfattning och att hennes förståalse kan skiljas från andras. Detta kan tolkas som att hon ser sig som en aktiv läsare och att hon även har fokus på sin egen lärprocess när hon skriver. Referathanteringen utgår från att det går att lämna källtextens specifika struktur och formuleringar för att istället lyfta ut relevant innehåll från olika delar av texten och skriva samman dem. När studenten ser att referera som att sammanfatta

3 Fx innebär här betyget $\mathrm{F}$ med möjlighet till komplettering för att bli godkänd. 
en källas idéinnehåll syns spår av källtexten genom att nyckelord och centrala idéer finns med, men studentens referat är ändå en egen text. I nedanstående excerpt har Petra och Mia sammanfattat två sidor av en artikel i en mening utifrån det som är relevant för deras undersökning. Nyckelord och centrala tankar från källtexten såsom "pedagogernas kompetens och intresse", "samspelets kvalité" och "bokval" återfinns i den egna texten. Däremot känns varken meningsbyggnad eller övriga ord igen från källtexten, vilket indikerar att texten är skriven med egna ord och ett uttryck för hur studenten förstått innehållet:

För att skapa stimulerande högläsningsaktiviteter ur ett pedagogiskt perspektiv finns det ett antal viktiga påverkansfaktorer såsom t.ex. pedagogernas kompetens och intresse, samspelets kvalité, bokval samt arbetet med att utveckla barnens ordförråd och slutledningsförmåga (Lennox 20I3, ss. 382-383). (Utdrag från Petras och Mias självständiga arbete)

När Petra och Mia sammanfattar texten på detta sätt kan det tolkas som att de frigör sig från källtextens formuleringar och struktur. De urskiljer att referera som att innehållet kan skrivas fram på ett nytt sätt, och att det kan komprimeras.

I denna kategori ses varje idéinnehåll som en helhet som behöver ha en egen sammanfattning. Detta innebär att referat radas upp efter varandra, i kortare eller längre avsnitt, utan att kopplas samman. Ett exempel på det är Lailas text där det finns nio referat. Dessa behandlas som separata informationsbitar och kopplas inte ihop med varandra. En sådan referathantering kan tolkas som att studenten ser ett behov av att redogöra för varje idéinnehåll för sig. Antingen urskiljs inte de kopplingar som finns mellan referaten, eller så ser inte studenten behovet av att som skribent göra dessa kopplingar - de lämnas istället åt läsaren att göra.

När att referera ses som att sammanfatta en källas idéinnehåll fokuserar således studenten på att förstå källtexten och att göra en kortare eller längre sammanfattning av den. Varje källtext ses som en separat enhet och kopplas inte språkligt samman med andra källor eller med egna resonemang.

\section{Ser att referera som att relatera källans idéinnehåll till annat idéinnehåll}

När referathanteringen erfars som att koppla källans idéinnehåll till ett annat idéinnehåll, används källan med ett särskilt syfte och sätts i ett sammanhang. Idéinnehållet behandlas fristående från den struktur och form som finns i källtexterna och kopplas ihop på en innehållslig nivå baserat på vad som är syftet med den egna texten. Referaten kan fungera som del i en argumentation eller ett resonemang.

När Paula pratar om hur hon hanterar referatskrivande uttrycker hon att hon som skribent måste göra val avseende innehållet i källtexten:

$\mathrm{Nu}$ har jag först och främst skumläst den här boken. Under tiden antecknar jag i boken om tankar eller sammanfattningar eller att jag skriver ut ett begrepp för att lättare kunna hitta det sen. Men sen att jag väljer det är för att jag tycker att det känns relevant i min studie, till mitt material. Jag har själv valt vad jag vill ha med och inte. Allt är inte passande. (Paula)

Detta kan tolkas som att referathantering innebär att välja ut de källtexter och delar av källtexter som är relevanta i relation till den egna uppgiften. Paula beskriver hur hon relaterar källtexten till sin egen studie. I Paulas egen text syns att hon använder källor för att understödja och utveckla ett resonemang: 


\section{Josefin Hellman och Anja Thorsten}

Att högre utbildning är centralt, och i viss mån nödvändigt, för en klassresa, blir tydligt när Bordieu [sic!] framhåller att utbildningssystemet är bärare av samhällets viktigaste socialiseringsmekanismer. (Utdrag från Paulas självständiga arbete)

I exemplet utgår Paula från Bourdieu i sitt resonemang. Källan får ett syfte i texten och sätts in i ett sammanhang och referatet kan tolkas som en del av en argumentation. Paulas tes "Att högre utbildning är centralt, och i viss mån nödvändigt, för en klassresa", stöds av referatet. I kategorin ses alltså referatet som något som ska fylla en funktion i den egna texten och källtexterna ses som bärare av olika idéer. Niklas beskriver att han kan påminna sig om tidigare texter han läst, leta upp dem och läsa dem igen för att de kan bidra med att belysa något specifikt $\mathrm{i}$ hans egen text. Detta kan tolkas som att Niklas erfar hanteringen av källtexter som del i ett större textarbete där den egna texten är i förgrunden och där källtexten ska passa in i den egna textens idéinnehåll.

När källtextens idéer behandlas kopplas de ihop med andra källors idéer och den egna texten får en struktur som är helt skild från källtexternas. Petras och Mias sammanfattning av forskningsläget kring högläsning i sitt självständiga arbete kan ses som exempel på hur olika källtexter kan vara bärare av olika idéer:

Forskningsläget kring högläsning och barns utveckling är otroligt samspelt där många studier lyfter fram högläsningens positiva aspekter utifrån flera olika perspektiv. T.ex social utveckling och lärande i samspel (Barton 2007, s. 3), hur högläsning stöttar barns tidiga litteracitet och språkutveckling såsom t.ex ordförråd (Beck \& McKeown 200I, s I8), läsförståelse (Dooley \& Matthews 2009, ss. 269-273) samt flera andra viktiga förmågor och områden.

I utdraget kan "social utveckling och lärande i samspel", "hur högläsning stöttar barns tidiga litteracitet och språkutveckling" och "läsförståelse" tolkas som Petras och Mias sammanfattning av källornas idéinnehåll. Referatens funktion i utdraget är i sin tur att beskriva forskningsläget om högläsningens positiva aspekter.

När att referera ses som att relatera källans idéinnehåll till annat idéinnehåll sker således en slags syntetisering. Källtexten ses som bärare av kunskap, idéer och faktainnehåll som kan sammanföras med andra källor och som kan användas för att skapa en hel, sammanhållen och väl understödd egen text.

\section{Ser att referera som att delta i ett vetenskapligt sammanhang}

När att referera ses som att delta i ett vetenskapligt sammanhang erfars användandet av källor som ett sätt att vara i del i ett pågående vetenskapligt samtal. Tidigare forskning används för att placera in det egna arbetet i ett fält. Moa beskriver det så här:

Jag utgår ju från någon annans grund. Det jag gjort och skriver måste ju baseras på något annat och därför refererar jag. / .../ för att visa att jag tar vid annans forskning. (Moa)

När Moa framhåller att hon utgår från andras forskning kan det tolkas som att hon ser sig som del i ett större forskningssammanhang, där hennes bidrag bygger vidare på tidigare forskningsresultat. Hon urskiljer att det egna textinnehållet är beroende av andras tidigare forskning och tankearbete. Även Niklas ger uttryck för att alla vetenskapliga texter finns i ett större sammanhang:

När man läser en uppsats vill man ju veta: 'Vad är den här egentligen byggd på?' / . . / Om man kollar referenslistan, då kan man se att den är byggd på alla de här. /.../ Man kan se grundbyggstenarna i slutet samlat. (Niklas) 
När Niklas beskriver att han vill veta vad en uppsats är byggd på kan det tolkas som att han ser en uppsats som del i en större helhet och att förståelsen av den helheten påverkar hur uppsatsen ska förstås. När han väljer ordet "grundbyggstenar" signalerar det att den källa som läses alltid vilar även på andras forskning och att det som forskare och student därför är viktigt att vara transparent med de källor som har använts. Forskningspublikationer och källor ses då inte som fristående verk, utan som del i ett vetenskapligt sammanhang.

Att se referathantering som att delta i ett vetenskapligt sammanhang innebär således att både källtexterna och den egna texten ses som del i ett större vetenskapligt sammanhang. Vilka källtexter som refereras och hur de hanteras hjälper läsaren av texten att placera in texten i ett fält.

\section{Kritiska aspekter}

Utifrån skillnaden mellan de fyra kategorierna påvisades fyra kritiska aspekter. För att kunna referera behöver studenterna urskilja att: A) texten kan separeras från dess form, B) det finns ett idéinnehåll i hela källtexten och i längre textavsnitt, C) källans idéinnehåll ska fylla en funktion i relation till den egna textens idéinnehåll och D) referathantering placerar den egna texten i ett vetenskapligt sammanhang. De kritiska aspekterna i relation till det fenomenografiska utfallsrummet presenteras i Figur 2.

Studenters kvalitativt skilda sätt att erfara och hantera

referatet i examinerande Kritiska aspekter

uppgifter för att referera

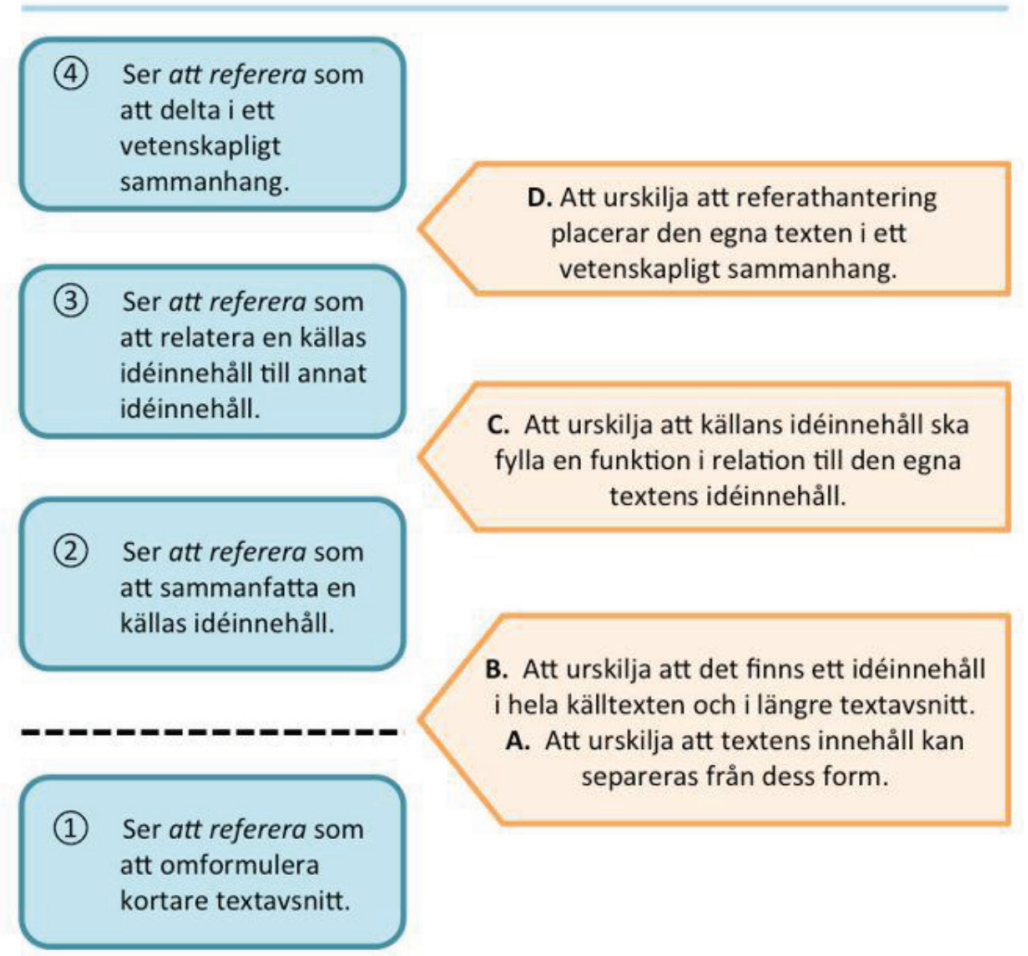

Figur 2. Utfalllsrum och kritiska aspekter avseende studenters erfarande av referathantering 


\section{A. Att textens innehåll kan separeras från dess form}

Studenten behöver urskilja att textinnehållet och textens form, det vill säga dess struktur, ordval och meningsbyggnad, går att separera och att innehållet behöver vara i fokus när källan ska användas. När studenterna i kategori I beskriver hur de byter ut ord och möblerar om i kortare textavsnitt liknar det patchwriting som Howard (1993) beskriver. För att studenten ska kunna gå ifrån denna strategi krävs att de urskiljer att ett och samma innehåll kan formuleras på olika sätt och att innehållet inte är inbäddat i specifika formuleringar.

\section{B. Att det finns ett idéinnehåll i hela källtexten och i längre textavsnitt}

I kategori I fokuserar studenten på kortare informationsbitar i texten. I kategori 2, däremot, ser studenten texten som en helhet som bär på ett eller flera idéinnehåll. Således behöver studenten urskilja och söka efter det idéinnehåll som finns i längre textavsnitt och i hela texten. Detta kan liknas vid det Elander et al. (20IO) uttrycker som att studenten behöver fokusera på textens kärnbudskap. Skillnaden mellan idéinnehåll, som vi beskriver det, och kärnbudskap är dock att det kan finnas flera idéinnehåll i en text. Ett kärnbudskap beskriver istället traditionellt hela textens övergripande budskap. När ett idéinnehåll i källan urskiljs av studenten kan även längre avsnitt komprimeras och sammanfattas med egna ord.

\section{Källans idéinnehåll ska fylla en funktion i relation till den egna textens idéinnehåll}

Studenten behöver använda källan aktivt i relation till syftet med den egna texten. Detta utgör skillnaden mellan kategori 2 och 3. I både kategori 2 och 3 urskiljs källans idéinnehåll, men i kategori 3 får en källas idéinnehåll en funktion i relation till den egna textens argumentation eller idéinnehåll. Härigenom blir referathanteringen en dialogisk aktivitet (jfr Lillis, 2003). Det gör också att den egna rösten i texten blir synlig och skribenten styr över innehållet i texten (jfr Hutchings, 20I4; Elander et al., 20IO). På så vis kan texten också bli självbärande.

\section{Att referathantering placerar in den egna texten i ett vetenskapligt sammanhang}

Studenten behöver urskilja att den egna texten placeras in i ett större vetenskapligt sammanhang med hjälp av de källor som används och den egna argumentation som förs. Skillnaden mellan kategori 3 och 4 består i att utsagor i kategori 3 fokuserar på den egna textens idéinnehåll, medan det i kategori 4 också beskrivs hur detta idéinnehåll finns i ett större sammanhang. I kategori 4 har referatets intertextuella aspekter vidgats bortom den examinerande uppgiften till att också innefatta ett specifikt vetenskapligt sammanhang (jfr Lea \& Street, I998; Pecorari \& Shaw, 20I2). När den här aspekten är urskild innebär det en insikt om att den egna texten placeras in i ett fält med hjälp av de källor som refereras i texten.

\section{DISKUSSION}

Referathantering är en nödvändig del av akademisk skriftspråkskompetens. Frågan är dock om det i högre utbildning idag undervisas om det som behövs för att ge studenterna möjlighet att lära sig denna färdighet. I relation till högskolans uppdrag om breddad rekrytering (se Högskolelag, 20I5) är detta särskilt angeläget. Resultatet i föreliggande studie bidrar med kunskap om vad undervisningen bör fokusera på för att studenter ska kunna referera. De kritiska aspekterna, som beskriver detta, kan användas skrivdidaktiskt av universitetslärare inom ramen för högskoleutbildning eller på lärosätenas språkverkstäder.

I likhet med tidigare studier indikerar resultatet i föreliggande studie att fokus på plagiering (se Refaei et al., 20I7; Badenhorst, 20I9) och antiplagieringsverktyg (se Weber-Wulff, 20I9) kan 
göra att studenten fastnar i språkliga detaljer. Uppmaningar som "skriv med egna ord" syftar till att få studenterna att släppa källtexten och formulera sig självständigt. I resultatet framkommer att sådana uppmaningar, istället för att leda uppmärksamheten mot källtextens innehåll, kan göra att studenterna fokuserar på specifika formuleringar i källtexten, textens form, vilket ökar risken för att plagiera. Studenter med mindre god referathantering (kategori I) fokuserade på att inte plagiera istället för att rikta sin energi mot att förstå och sammanfatta det de läst. Att undvika plagiering tycks således stå i vägen för att utveckla referatkunnandet. När studenten också uppfattar att texten ska ha ett akademiskt språk blir det ännu svårare. Om studentens ordförråd och språkliga färdighet inte räcker till kan hen behöva skriva med ett språk som uppfattas som mindre akademiskt. Att sammanfatta "med egna ord" kan därför stå i konflikt med akademiska skriftspråksnormer.

I föreliggande såväl som tidigare studier framkommer att vissa studenter plagierar (se Ask, 2007; Staaf, 20I5). Frågan är om detta ska ses som ett utvecklingssteg och att kategori I innebär urskiljanden som är nödvändiga även för de andra kategorierna, eller om de förhållningssätt som framkommer i kategori I inte förbereder för ett mer avancerat skrivande. Liknande diskussioner har förts om patchwriting (se Howard et al., 20IO; Vardi, 20I2). Denna fråga belyser således ett område som behöver beforskas ytterligare.

För att kunna referera korrekt visar föreliggande studie att studenterna behöver kunna sammanfatta idéinnehållet i varje text, men att de också behöver kunna relatera detta innehåll till andra källtexter och till den egna textens syfte. Referathantering blir då en dialogisk process (jfr Lillis, 2003; Hutchings, 20I4). Det innebär att även om källtextens innehåll måste stämma med ursprungskällan, så kan den användas, kopplas ihop med och fylla en ny funktion i ett nytt sammanhang (jfr Jakobs, 2003; Eriksson \& Mäkitalo, 20I3). Undervisningen bör därför synliggöra referathanteringens intertextuella aspekter. Sådan kunskap kan anses knuten till ett allmänakademiskt normlager i relation till akademisk skriftspråkskompetens (jfr Blückert, 20Io). Den ämnesspecifika undervisningen bör också placera referathanteringen i ett vetenskapligt sammanhang och synliggöra de normer och konventioner som finns inom fältet (jfr Vardi, 20I2; Pecorari \& Shaw, 20I2).

I föreliggande studie framkommer några utsagor där studenter ger uttryck för att de källor de använder placerar in den egna texten i ett vetenskapligt sammanhang (kategori 4). Dessa utsagor vittnar om en begynnande medvetenhet om refererandets betydelse för ett gemensamt kunskapsbygge inom olika fält. Även om kategorin finns med i föreliggande studie, så skulle dess innebörd kunna fördjupas genom en analys av intervjuer och texter från etablerade forskare som behärskar refererandet. Det skulle bidra med att kunnandet att referera skulle kunna beskrivas ytterligare.

Resultatet indikerar också att självständiga arbeten i större utsträckning bjuder in till en mer komplex referathantering än hemtentamina. Relationen mellan uppgifternas utformning och vad som görs möjligt för studenten att urskilja avseende referathantering skulle därför behöva undersökas vidare. Det utfallsrum och de kritiska aspekter som beskrivs i resultatet gör således inte anspråk på att vara heltäckande. De har framkommit i en specifik kontext, en språkverkstad, dit studenter vänder sig för att få stöd i sitt akademiska skrivande. Samtliga studenter läste på utbildningar inom humaniora och samhällsvetenskap. Referathanteringen i föreliggande studie riktas emellertid mot allmänakademiska normer, vilket innebär att resultatet kan vara användbart även i andra sammanhang och inom andra universitetsutbildningar än där studien genomfördes. Vid undervisning i högre utbildning behöver dock resultatet ställas i relation till det egna fältet och de specifika normer för referathantering som finns där. De kan då bli användbara 


\section{Josefin Hellman och Anja Thorsten}

genom det Larsson (2009) benämner som kontextlikhet, att de är en teoretisk beskrivning av vad kunnandet innebär och att denna beskrivning kan användas som utgångspunkt för lärare som undervisar om referathantering och för forskare som vill fördjupa kunskapen om området.

\section{FÖRFATTARPRESENTATIONER}

Josefin Hellman arbetar som språkverkstadspedagog vid Stockholms universitet. På Studie- och språkverkstaden stöttar hon studenter med undervisning $\mathrm{i}$ akademiskt skrivande och studiestrategier samt håller fortbildande workshoppar för lärare. Hon har lärarbakgrund och är leg. gymnasielärare i svenska och psykologi.

Anja Thorsten är universitetslektor i pedagogik vid Linköpings universitet. Hon har lärarbakgrund och arbetar nu med lärarutbildning, lärarfortbildning och forskning med fokus på skrivundervisning, didaktiskt ledarskap och praktiknära forskning.

\section{REFERENSER}

Ask, S. (2007). Vägar till ett akademiskt skriftspråk (Diss, Växjö universitet). Växjö: Växjö universitet. Hämtad från http://urn.kb.se/resolve?urn=urn:nbn:se:vxu:diva-1276

Badenhorst, C. M. (2019). Literature reviews, citations and intertextuality in graduate student writing. Journal of Further and Higher Education, 43(2), 263-275. https://doi.org/10.1080/0309877X.2017. 1359504

Blückert, A. (2010). Juridiska - ett nytt språk?: En studie av juridikstudenters språkliga inskolning (Diss, Stockholms universitet). Stockholm: Stockholms universitet. Hämtad från http://urn.kb.se/resolve? urn=urn:nbn:se:uu:diva-111807

Bryman, A. (2011). Sambällsvetenskapliga metoder (2., [rev.] uppl.). Malmö: Liber.

Dahlgren, L.-O. \& Johansson, K. (2015). Fenomenografi. I A. Fejes \& R. Thornberg (Red.), Handbok i kvalitativ analys (2 utök. uppl., s. 162-175). Malmö: Liber.

Elander, J., Pittam, G., Lusher, J., Fox, P. \& Payne, N. (2010). Evaluation of an intervention to help students avoid unintentional plagiarism by improving their authorial identity. Assessment \& Evaluation in Higher Education, 35(2), 157-171. https://doi.org/10.1080/02602930802687745

Eriksson, A.-M. \& Mäkitalo, Å. (2013). Referencing as practice: Learning to write and reason with other people's texts in environmental engineering education. Learning, Culture and Social Interaction, 2(3), 171-183. https://doi.org/10.1016/j.lcsi.2013.05.002

Gravett, K. \& Kinchin, I. M. (2020). Referencing and empowerment: Exploring barriers to agency in the higher education student experience. Teaching in Higher Education, 25(1), 84-97. https://doi.org/ $10.1080 / 13562517.2018 .1541883$

Hoel, T. L. (2010). Skriva på universitet och högskolor: En bok för lärare och studenter (1. uppl.; S. Andersson, övers.). Lund: Studentlitteratur.

Hounsell, D. (1997). Contrasting conceptions of essay-writing. I F. Marton (Red.), The experience oflearning: Implications for teaching and studying in higher education (2:a uppl., s. 106-125). Edinburgh: Scottish Academic Press.

Howard, R. M. (1993). A plagiarism pentimento. Journal of teaching writing, 11(2), 233-46.

Howard, R. M., Serviss, T. \& Rodrigue, T. K. (2010). Writing from sources, writing from sentences. Writing and Pedagogy, 2(2), 177-192. https://doi.org/10.1558/wap.v2i2.177

Hutchings, C. (2014). Referencing and identity, voice and agency: Adult learners' transformations within literacy practices. Higher Education Research \& Development, 33(2), 312-324. https://doi.org/10.108 $0 / 07294360.2013 .832159$

Högskoleförordning, SFS 1993:100.

Högskolelag, SFS 2015:1208. 
Jakobs, E.-M. (2003). Reproductive writing-Writing from sources. Journal of Pragmatics, 35(6), 893-906. https://doi.org/10.1016/S0378-2166(02)00124-8

Kvale, S. \& Brinkmann, S. (2014). Den kvalitativa forskningsintervjun. Lund: Studentlitteratur.

Larsson, S. (2009). A pluralist view of generalization in qualitative research. International journal of research \& method in education, 32(1), 25-38. https://doi.org/10.1080/17437270902759931

Lea, M. R. \& Street, B. V. (1998). Student writing in higher education: An academic literacies approach. Studies in higher education, 23(2), 157-172. https://doi.org/10.1080/03075079812331380364

Lennartson-Hokkanen, I. (2016). Organisation, attityder, lärandepotential: Ett skrivpedagogiskt samarbete mellan en akademisk utbildning och en spräkverkstad (Diss, Stockholms universitet). Stockholm: Stockholms universitet. Hämtad från http://urn.kb.se/resolve?urn=urn:nbn:se:su:diva-134828

Lillis, T. (2003). Student writing as' academic literacies': Drawing on Bakhtin to move from critique to design. Language and education, 17(3), 192-207. https://doi.org/doi:10.1080/09500780308666848

Lo, M. L. (2014). Variationsteori: För bättre undervisning och lärande. Lund: Studentlitteratur.

Malmström, M. (2017). Synen på skrivande: Föreställningar om skrivande i mediedebatter och gymnasieskolans läroplaner. Lund: Lunds universitet, Institutionen för utbildningsvetenskap.

Marton, F. (1981). Phenomenography - Describing conceptions of the world around us. Instructional science, 10(2), 177-200.

Marton, F. (2015). Necessary conditions of learning. London: Routledge.

Marton, F. \& Booth, S. (2000). Om lärande. Lund: Studentlitteratur.

Pang, M. F. \& Ki, W. W. (2016). Revisiting the idea of "critical aspects". Scandinavian Journal of Educational Research, 60(3), 323-336.

Pecorari, D. (2019). Can plagiarism be defined? I D. Pecorari \& P. Shaw (Red.), Student plagiarism in higher education (s. 12-27). London: Routledge.

Pecorari, D. \& Shaw, P. (2012). Types of student intertextuality and faculty attitudes. Journal of Second Language Writing, 21(2), 149-164. https://doi.org/10.1016/j.jslw.2012.03.006

Refaei, B., Kumar, R., Wahman, M. L. \& Peplow, A. B. (2017). Supporting Source Integration in Student Writing. International Journal of Teaching and Learning in Higher Education, 29(3), 534-544.

Runesson, U. (2017). Learning study. I I. Carlgren \& I. Eriksson (Red.), Undervisningsutvecklande forskning: Exemplet Learning study (s. 17-30). Stockholm: Stockholm. University, Department of Humanities and Social Sciences Education.

Staaf, P. (2015). Som man frägar fär man svar: Andraspråksstudenter möter lärares krav i hemtentor (Lic. -avh., Malmö högskola). Malmö: Malmö högskola. Hämtad från http://urn.kb.se/resolve?urn=urn:nbn:se: lnu:diva-42916

Sutherland-Smith, W. (2019). Is student plagiarism still a serious problem in universities today? I D. Pecorari \& P. Shaw (Red.), Student plagiarism in higher education (s. 47-61). London: Routledge.

Thorsten, A. (2018). Berättelseskrivande i skolan: Att studera, beskriva och utveckla ett kunnande (Diss, Linköpings universitet). Linköping: Linköpings universitet. Hämtad från http://www.diva-portal.org/ smash/record.jsf ?pid=diva2:1235493

UKÄ. (2019). Disciplinärenden 2018 vid universitet och högskolor (Nr 2019:14). Stockholm: Universitetskanslerämbetet.

Vardi, I. (2012). Developing students' referencing skills: A matter of plagiarism, punishment and morality or of learning to write critically? Higher Education Research \& Development, 31(6), 921-930.

Vetenskapsrådet. (2017). God forskningssed. Stockholm: Vetenskapsrådet. Hämtad från Vetenskapsrådets webbplats https://bit.ly/3q6zt5h

Weber-Wulff, D. (2019). Why does plagiarism detection software not find all plagiarism? I D. Pecorari \& P. Shaw (Red.), Student plagiarism in higher education. London: Routledge.

Östlund-Stjärnegårdh, E. (2006). Att förmedla egna och andras tankar: Om gymnasisters källhantering i det nationella provets skrivuppgift. Uppsala: Uppsala universitet, Gruppen för nationella prov i svenska och svenska som andraspråk. 